\title{
New Insights into Mechanisms of Atrial Fibrillation
}

\author{
B. ALDHOON ${ }^{1}$, V. MELENOVSKÝ ${ }^{1}$, P. PEICHL ${ }^{1}$, J. KAUTZNER ${ }^{1}$ \\ ${ }^{1}$ Department of Cardiology, Institute for Clinical and Experimental Medicine, Prague, Czech \\ Republic
}

Received July 21, 2008

Accepted January 7, 2009

On-line February 27, 2009

\begin{abstract}
Summary
Although atrial fibrillation (AF) is the most common cardiac arrhythmia in clinical practice, precise mechanisms that lead to the onset and persistence of AF have not completely been elucidated. Over the last decade, outstanding progress has been made in understanding the complex pathophysiology of AF. The key role of ectopic foci in pulmonary veins as a trigger of AF has been recognized. Furthermore, structural remodeling was identified as the main mechanism for AF persistence, confirming predominant role of atrial fibrosis. Systemic inflammatory state, oxidative stress injury, autonomic balance and neurohormonal activation were discerned as important modifiers that affect $A F$ susceptibility. This new understanding of AF pathophysiology has led to the emergence of novel therapies. Ablative interventions, renin-angiotensin system blockade, modulation of oxidative stress and targeting tissue fibrosis represent new approaches in tackling AF. This review aims to provide a brief summary of novel insights into AF mechanisms and consequent therapeutic strategies.
\end{abstract}

\section{Key words}

Atrial fibrillation • Triggers • Electrical remodeling • Structural remodeling • Fibrosis

\section{Corresponding author}

Bashar Aldhoon, Department of Cardiology, Institute for Clinical and Experimental Medicine - IKEM, Vídeňská 1958/9, 140 21, Prague 4, Czech Republic. E-mail: bashar.aldhoon@ikem.cz

\section{Introduction}

Atrial fibrillation (AF) is the most common cardiac arrhythmia that affects approximately $1 \%$ of the general population and up to $8 \%$ of subjects over the age of 80 years (Fuster et al. 2006). AF is associated with decreased quality of life, increased morbidity and a $30 \%$ higher risk of death (Benjamin et al. 1998), and thus is a major contributor to cardiovascular mortality. Up to $15 \%$ of all strokes are attributable to this disorder. AF is characterized by very rapid, chaotic electrical activity of the atria, resulting in accelerated and irregular ventricular activity, loss of atrial mechanical function and increased risk of atrial clot formation. AF can occasionally affect a structurally normal heart of otherwise healthy individuals (so-called "lone AF"), but most typically it occurs in subjects with previous cardiovascular damage due to hypertension, coronary artery disease and diabetes. The aim of this article is to review current understanding of the mechanisms responsible for the onset and persistence of the arrhythmia with emphasis on the role of atrial fibrosis as the main course of structural remodeling.

\section{Conceptual models of atrial fibrillation}

The mechanisms of spatiotemporal organization of electrical activity in the atria during $\mathrm{AF}$ have not conclusively been understood. Three models were proposed (Garrey 1924) but applicability of these models is still disputed. The focal mechanism theory with fibrillatory conduction stands on the notion that AF is provoked and perhaps also driven further by the rapid firing of a single or multiple ectopic foci. This theory has gained recent support from clinical observation by Haissaguere et al. (1998) that paroxysmal AF can be cured by focal ablation of ectopic activity in the pulmonary veins. The single circuit re-entry theory of AF 
assumes the presence of a single dominant re-entry circuit - "mother rotor" with a break-up of emanating waves in the atrial tissue of variable electrical properties. The multiple wavelet theory of $\mathrm{AF}$ assumes the presence of multiple reentry circuits with randomly propagating wave-fronts that must find receptive tissue in order to persist (Moe et al. 1964). The shortening of the refractory period of atrial myocytes and the slowing of conduction velocity - salient features of electrical remodeling - both help to stabilize the arrhythmia by decreasing circuit size. This theory has support in the experimental work of Allessie et al. (1985). It appears that all three concepts are non-exclusive and each may be applicable to certain subgroups of AF patients, or that they may even coexist in the same subject during different stages of $\mathrm{AF}$ development.

The probability of development of $\mathrm{AF}$ is also affected by external modifiers. According to Coumel's triangle of arrhythmogenesis, three cornerstones are required in the onset of clinical arrhythmia (Farré and Wellens 2004) - the arrhythmogenic substrate, the trigger factor and the modulation factors such as autonomic nervous system or inflammation. The interplay between trigger, substrate and the modulation factors determines the clinical picture of the arrhythmia. In the absence of a significant substrate for $\mathrm{AF}$ persistence, i.e. in a structurally normal heart, the triggering ectopic activity leads to self-terminating episodes of AF - paroxysmal AF. On the other hand, even limited ectopy in extensively remodeled atria can start $\mathrm{AF}$ that persists until its termination by cardioversion (persistent $\mathrm{AF}$ ) or indefinitely (permanent AF). Once established, AF itself alters electrical and subsequently structural properties of the atrial tissue and these changes cause or "beget" further AF self-perpetuation (Wijffels et al. 1995).

\section{Triggers of atrial fibrillation}

\section{Role of the pulmonary veins}

Twelve years ago, Haissaguerre et al. (1998) published a landmark observation describing the causal role of pulmonary veins in the inception of AF. However, the mechanism of impulse initiation in the pulmonary veins has still not been defined. Abnormal automaticity, triggered activity and the re-entry mechanism were proposed.

There is more evidence showing that the pulmonary veins are capable of automaticity. Specialized cardiac cells associated with pacemaking, resembling pale (P) and Purkinje cells, have been observed in the pulmonary veins in rats, dogs and humans (Wit and Boyden 2007). These cells might be residua of the embryonic myocardium. Developmental studies have shown that the complicated looping process of the heart tube brings together the essential parts of the sino-atrial and primary ring myocardium which are embryonic precursors of definitive conduction system. During this development, sino-atrial tracts are formed that run between the sino-atrial and the atrio-ventricular node, together with tracts surrounding the pulmonary veins and the coronary sinus (Gittenberger-de Groot et al. 2003).

Honjo et al. (2003) showed that infusion of ryanodine, an inhibitor of $\mathrm{Ca}^{2+}$ release from the sarcoplasmic reticulum, shifts the cardiac pacemaker from the sino-atrial node to a focus near the right pulmonary vein. Zhou et al. (2002) demonstrated that such focal activity within the pulmonary veins may be enhanced in persistent AF, suggesting that pulmonary veins may not only provoke $A F$, but they may also be important in sustaining re-entry. This may consequently contribute to $\mathrm{AF}$ persistence. Experiences with $\mathrm{AF}$ ablation show that radiofrequency elimination of such foci within PV may terminate the arrhythmia.

The myocardial architecture in human pulmonary veins is highly variable. The transition from atrial to venous walls is gradual as the left atrial myocardial sleeves overlap with smooth muscle of the venous myocardium (Ho et al. 1999). The muscle fibers in pulmonary veins are usually orientated perpendicularly to the blood flow. Such an arrangement, together with increased anisotropy due to ageing-induced fibrosis, may facilitate re-entry within the pulmonary veins. Furthermore, the cellular properties of pulmonary-vein cardiomyocytes, such as shorter action potential and smaller zero-phase upstroke velocities than in the left atrium, are in favor of re-entry (Ehrlich et al. 2003).

\section{Triggers of atrial fibrillation as a therapeutic target}

Optical mapping studies documented the location of preferential re-entry circuits that occur in the pulmonary vein region in canine models of AF (Arora et al. 2003). Electrophysiological studies in patients with paroxysmal atrial fibrillation found re-entry circuits located mainly at the junction of pulmonary vein and left atrial junction (Atienza et al. 2006). Accordingly, the pulmonary veins emerged as a potential target for ablation. Several approaches were developed: focal ablation within the pulmonary veins, followed later by 


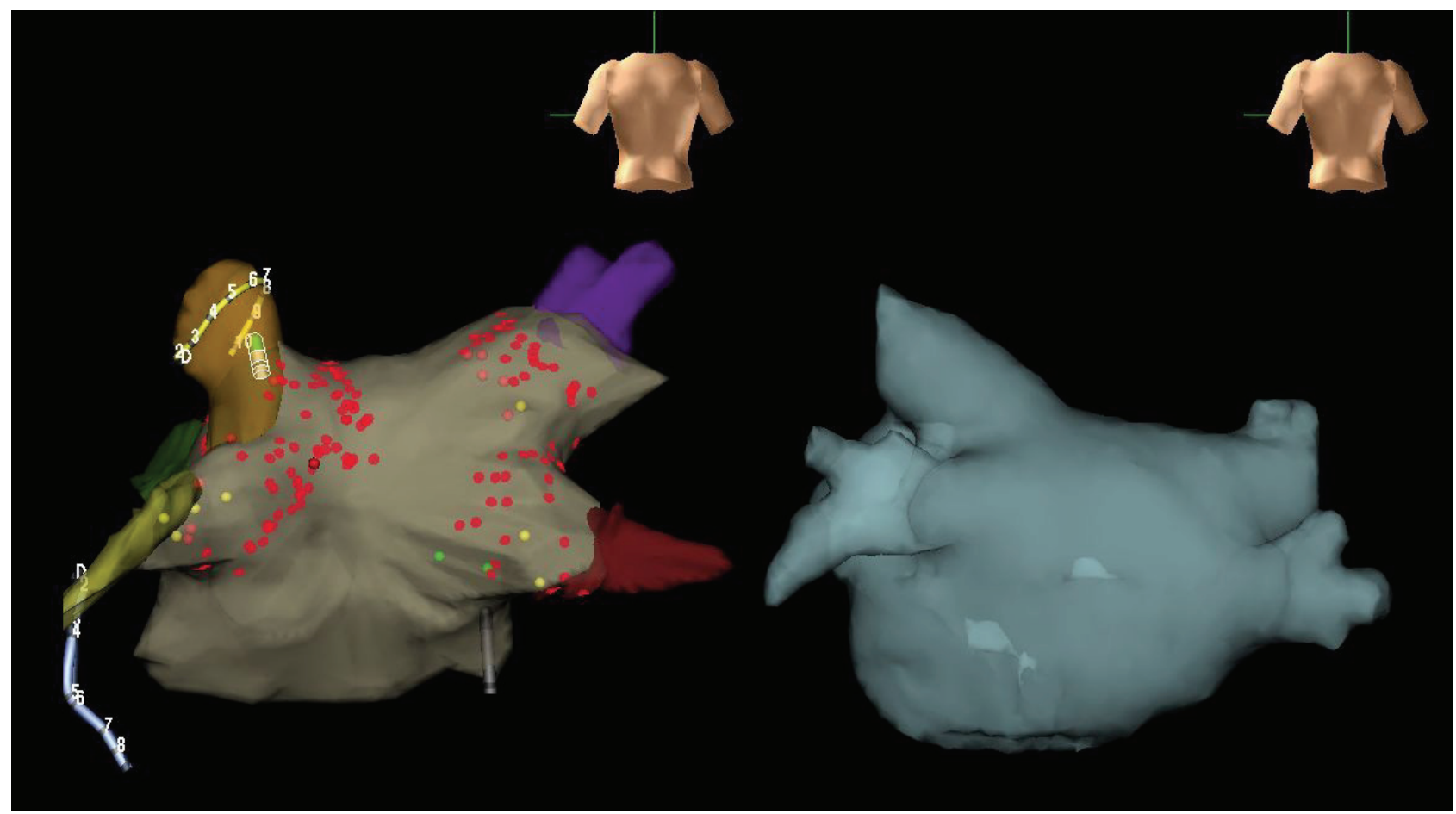

Fig. 1. Scheme of circumferential lesions created in patients with paroxysmal atrial fibrillation undergoing catheter ablation and isolation of pulmonary veins. Ablation sites (red dots) are projected on 3D map of the left atrium in posterior view obtained by means of Nav X mapping system (St. Jude Medical). On the right side of the panel is corresponding CT angiogram of the left atrium and pulmonary veins.

segmental ostial ablation guided by pulmonary vein potentials or circumferential pulmonary vein ablation, and the creation of linear lesions. Currently, circumferential ablation in combination with linear lesions in both atria appears to be the most effective approach (Fig. 1). This complex procedure carries a significantly higher success rate, with about $85 \%$ of patients with paroxysmal AF being cured and antiarrhythmic drug free.

\section{Other focal triggers of atrial fibrillation}

Triggered activity similar to pulmonary vein foci has been seen in the musculature of other cardiac structures. Focal atrial tachycardia and fast repetitive activity after rapid atrial-pacing have been shown to originate from the musculature of the coronary sinus, the superior vena cava, and the ligament of Marshal (Wit and Boyden 2007).

Optical mapping-studies in animal models point to a dominant role of the posterior left atrium in sustaining AF (Atienza and Jalife 2007) where the AF is maintained by functional micro-reentry circuits localized in the proximity of the junction of the pulmonary veins and the left atrium. During the isolation of pulmonary veins by radiofrequency energy, AF terminates usually before the full electrical isolation is accomplished, probably due to disruption of these re-entry circuits at the posterior left atrium. From our clinical experience, greater procedural success is achieved if radiofrequency isolation of the pulmonary vein is accomplished with larger encircling lesions that cover most of the posterior wall of the left atrium. Another approach has been advocated by Nademanee et al. (2004), consisting of mapping areas with complex and fractionated electrograms and subsequent catheter ablation. These sites may reflect regions with functional micro-reentrant circuits or firing of the autonomic ganglia. Catheter ablation of these spots is able to abolish AF without the need for isolation of the pulmonary veins.

\section{Modifiers of AF substrate}

\section{The autonomic nervous system}

An imbalance in autonomic nervous system activity can result in significant changes of cardiac electrophysiological properties of the atrial myocardium which may facilitate the induction of AF. Vagal nerve stimulation causes the shortening of an effective refractory period and facilitates induction of $\mathrm{AF}$ and re-entrant atrial arrhythmias (Zipes et al. 1974). Patients with this vagal-dependent AF are mostly middle-aged males without structural heart disease but with high basal 
parasympathetic tone. Increased sympathetic tone may also facilitate the development of AF. Modification of sympathetic responsiveness by adrenergic beta-receptor blockade might be useful in preventing AF recurrence after sinus rhythm restoration (Kühlkamp et al. 2000). Excessive adrenergic stimulation is believed to be dominant mechanisms in postoperative AF. Prophylactic use of beta-blockers reduces the incidence of postoperative AF (Maisel et al. 2001).

The cardiac autonomic nervous system can be divided into extrinsic and intrinsic components (Ardell 1994). The extrinsic part consists of brain nuclei and chains of ganglia along the spinal cord with axons terminating in the heart. The intrinsic component is composed of a network formed of axons and autonomic ganglia (ganglion plexus) embedded within epicardial fat pads located above both atria and ventricles (Armour et al. 1997). One important part of the ganglion plexus has been located in close proximity to the left-atrial pulmonary vein junction. This area is rich in autonomic innervations. Recent studies have shown that stimulation of the plexus in this location can convert focal activity in the pulmonary veins into AF (Scherlag et al. 2005).

\section{Autonomic nervous system as a therapeutic target}

Some research groups have hypothesized that elimination of the ganglion plexus, particularly at the pulmonary-vein atrial junction, could increase the success rate of AF ablation (Pappone et al. 2004). In an experimental study in dogs, radiofrequency ablation of epicardial fat pads substantially reduced the inducibility of AF during vagal stimulation which immediately followed the ablation procedure. However, after 4 weeks of recovery, the AF inducibility was unchanged in comparison to the baseline (Oh et al. 2006). The anatomy of the pulmonary-vein atrial junction seems to be more complex than previously thought. Adrenergic and cholinergic nerves have the highest densities within $5 \mathrm{~mm}$ on the atrial side of the junction, and they are highly co-located (Tan et al. 2006). This makes selective ablation of either vagal or sympathetic nerves in this location practically impossible. Furthermore, after catheter ablation in these sites, a sympathetic hyperinnervation could follow due to neural plasticity (Okuyama et al. 2004). Radiofrequency catheter ablation is followed by significant elevation of the systemic nerve growth factor concentrations (Kangavari et al. 2006). This may well play a role in early recurrence of AF after ablation. Further studies in this area are needed to elucidate the benefit of ganglionic plexus ablation in AF therapy.

\section{Atrial substrate and remodeling}

Remodeling involves changes in the structure, function and geometry of the atria, modifications of atrial electrical and contractile properties, and changes in the amount and the composition of the extracellular matrix. Together, these alterations create an arrhythmogenic substrate essential for the persistence of AF. An important source of atrial remodeling can be AF itself, mainly due to the effects of rapid atrial rate and elevated filling pressure. Another cause of remodeling are cardiovascular factors damaging the heart even prior to the onset of arrhythmia; namely hypertension, coronary disease, diabetes or hemodynamic overload due to valve disease. There are two distinct forms of atrial remodeling - electrical and structural, which differ in etiology, involved mechanisms and potential reversibility (Table 1). Electrical remodeling occurs due to the effects of a high atrial rate and includes changes in ionic properties of the atrial myocytes, particularly the shortening of refractoriness and the slowing of conduction velocity (Pandozi et al. 1998).

\section{Electrical remodeling}

The concept of atrial remodeling due to chronic high atrial rates or "tachycardia-induced electrical remodeling“" was first described in experimental studies (Morillo et al. 1995, Wijffels et al. 1995). It has been found in animal models that AF is sustained due to marked shortening of the atrial refractory period and due to an abnormal rate-adaptation of refractoriness, and that these changes involve alterations of intracellular $\mathrm{Ca}^{2+}$ handling. With each action potential, $\mathrm{Ca}^{2+}$ enters the cell through Ltype $\mathrm{Ca}^{2+}$ channels. Under the conditions of high atrial rate, $\mathrm{Ca}^{2+}$ loading is substantially enhanced. Cardiomyocytes prevent dangerous $\mathrm{Ca}^{2+}$ overload by the activation of shortterm and long-term protective mechanisms, such as functional inactivation L-type calcium current $\left(\mathrm{I}_{\mathrm{CaL}}\right)$ or down-regulation of mRNA encoding L-type calcium channels (Yue et al. 1997). A significant reduction in the $\mathrm{Na}^{+}$current $\left(\mathrm{I}_{\mathrm{Na}}\right)$ density was also reported in a dog model (Gaspo et al. 1997). The decrease in $\mathrm{I}_{\mathrm{CaL}}$ leads to a reduction in the action potential duration, whereas the reduction in the $\mathrm{I}_{\mathrm{Na}}$ may contribute to the decrease in the conduction velocity. These changes concurrently facilitate the re-entry mechanism. However, electrical remodeling is 
Table 1. Two forms of atrial remodeling.

\section{Electrical}

Cellular and tissue
characteristics
Refractory period
Conduction velocity
Clinical scenario

Animal model

Reversibility
Alterations in ionic changes L-type, $\mathrm{Ca}^{2+}$ current down-regulation

\section{$\downarrow \downarrow \downarrow$}

$\leftrightarrow$ or $\uparrow$

Atrial tachycardia, paroxysmal AF

Rapid atrial pacing

(Wijffels et al. 1995)
Structural

myocyte loss, diffuse and patchy

fibrosis, scarring

$\leftrightarrow$

$\downarrow \downarrow$

$\mathrm{AF}$ in CHF

Rapid ventricular pacing

(Li D et al. 1999) still completely reversible after restoration of sinus rhythm. In fact, even after prolonged periods of $\mathrm{AF}$ (months to years), the atrial refractoriness returns to normal within a few days after sinus rhythm restoration.

The propensity to develop and sustain arrhythmia can be modified by the administration of antiarrhythmic drugs. The most frequently used drugs for rhythm control in AF patients are class I and III antiarrhythmic agents, which are typically sodium-channel or potassium-channel blockers, respectively.

The main electrophysiologic effect of many antiarrhythmic drugs is prolongation of the atrial action potential, reversing so electrical remodeling. Prolongation of action potential in the atria can then prevent recurrence of AF. Amiodarone prevented tachycardia-induced atrial electrophysiological remodeling, both at the level of atrial electrical properties and ion-channel subunit expression (Shinagawa et al. 2003). However, the effects of antiarrhythmic drugs in tissue affected by $\mathrm{AF}$ are reduced. In a mathematical model of the human atrial myocyte electrophysiology, the effect of $\mathrm{I}_{\mathrm{Kr}}$ blockade on the duration of the action potential was reduced in remodeled atrial cells (Courtemanche et al. 1999). In AF-remodeled goat atria, the effects of dofetilide on refractoriness were decreased (Blaauw et al. 2004). Similarly, flecainide has reduced efficacy in atrial tissue changed by tachycardiainduced remodeling, but it recovers its antiarrhythmic action after cardioversion of AF (Teileman et al. 2005).

\section{Structural remodeling}

The second and probably more important form of atrial remodeling is "structural remodeling". Experimental studies (Ausma et al. 1997) demonstrated that prolonged rapid atrial pacing induces changes in atrial myocytes such as an increase in cell-size, myolysis, perinuclear accumulation of glycogen, alterations in connexin expression, fragmentation of sarcoplasmic reticulum and changes in mitochondrial shape. At the tissue level, structural remodeling is characterized by myocyte cell loss, and by changes in extracellular matrix composition, with both diffuse interstitial and patchy fibrosis. Similar alterations were also observed in the atrial tissue of patients with AF (Frustaci et al. 1997). Structural remodeling results in electrical tissue non-homogeneity, slowed conduction and electrical uncoupling, facilitating $\mathrm{AF}$ continuation without inducing changes in atrial action potential properties. In contrast to electrical remodeling, structural changes are far less reversible and they tend to persist even after the re-establishment of sinus rhythm.

Structural remodeling can also precede the onset of $\mathrm{AF}$ since it emanates from cardiac damage due to coronary artery disease, hemodynamic overload from valve disease or hypertension. Interestingly, incident $\mathrm{AF}$ in the Framingham study was not related to mean arterial blood pressure, but it was much more predicted by pulse pressure, a surrogate marker of arterial stiffness (Mitchell et al. 2007). This suggests that cardiac atrial fibrosis in hypertensive patients may be a part of more widespread changes in the extracellular matrix of the cardiovascular system, affecting not only the heart but also the large arteries.

An illustrative example of structural remodeling are changes observed in the atria in chronic heart failure (CHF), characterized by dilatation of the atria, with marked diffuse and patchy interstitial fibrosis and scarring. The degree of structural pathology relates to the degree of LA enlargement. In human atrial specimens, the amount of fibrosis was greater in the atria of patients with $\mathrm{AF}$ as opposed to those with sinus rhythm (Boldt et al. 2004). Structural remodeling explains why $\mathrm{CHF}$ is the most common clinical cause of $\mathrm{AF}$ and why $\mathrm{CHF}$ precedes $\mathrm{AF}$ about as often as AF precedes CHF. 


\section{Mechanisms of atrial fibrosis}

The precise mechanism and signaling pathways involved in structural remodeling and atrial fibrosis are still unknown. The renin-angiotensin system, the transforming growth-factor $\beta 1$ (TGF- $\left.\beta_{1}\right)$ pathway, inflammation and reactive oxygen species are involved in the development of atrial fibrosis. Profibrotic signals act on the balance between matrix metalloproteinases (MMPs) - main enzymes responsible for degradation of extracellular matrix - and their local tissue inhibitors (TIMPs). Furthermore, profibrotic signals stimulate the proliferation of fibroblasts and extracellular deposition of fibronectin, collagens I and III, proteglycans and other matrix components.

\section{The renin-angiotensin system}

The development of atrial fibrosis in CHF is angiotensin-II dependent. Li et al. (2001) showed in a canine CHF model, that atrial angiotensin-II concentrations and mitogen-activated protein kinases (MAPKs) were increased by ventricular pacing, together with substantial changes in phosphorylated forms of c-Jun N-terminal kinase (JNK), extracellular signal-regulated kinase (ERK), and p38-kinase. In addition, enalapril significantly reduced tachypacing-induced changes in atrial angiotensin-II concentrations and ERK expression. Increased tissue angiotensin-II and phosphorylated MAPKs are associated with apoptosis, leukocyte infiltration, and tissue fibrosis (Cardin et al. 2003). The effects of angiotensin-II on extracellular matrix composition and collagen expression are partly mediated by the local production of cytokine TGF- $\beta_{1}$ (Kupfahl et al. 2000).

\section{$T G F-\beta_{1} / S M A D$ pathway}

TGF- $\beta_{1}$ is a profibrotic cytokine that controls the production and composition of the extracellular matrix in many tissues including the heart, vessel wall, the lungs and the liver (Khan and Sheppard 2006). Overexpression of TGF- $\beta_{1}$ enhances extracellular matrix synthesis and organ fibrosis. In the cardiovascular system, TGF- $\beta_{1}$ plays an important role in scar formation after myocardial infarction, cardiac hypertrophy, the stabilization of atherosclerotic plaque (Cipollone et al. 2004) and in atrial scarring due to CHF (Everett and Olgin 2007).

TGF- $\beta_{1}$ production in the myocardium is increased by angiotensin-II (Campbell and Katwa 1997) and $\mathrm{AT}_{1}$ receptor-antagonists inhibit $\mathrm{TGF}-\beta_{1}$ gene expression (Kim et al. 1995). Importantly, administering of
angiotensin-II does not induce cardiac hypertrophy in mice lacking the TGF- $\beta_{1}$ gene (Schultz et al. 2002). Following the synthesis in cardiac fibroblasts and release into the extracellular space, TGF- $\beta_{1}$ binds to the TGF- $\beta_{1}$ receptor. This leads to the phosphorylation of intracellular SMAD proteins that form complexes which translocate into the nucleus where they regulate DNA transcription. In addition, the activation of the TGF- $\beta_{1}$ receptor also leads to the expression of a connective-tissue growth-factor (CTGF) that is released locally and acts in a paracrine way which further stimulates extra-cellular matrix-protein expression and fibrosis.

The critical role of the TGF- $\beta_{1}$ pathway in the incidence of $\mathrm{AF}$ has been shown in transgenic mice overexpressing constitutively active form of TGF $-\beta_{1}$ which led to selective atrial fibrosis, increased conduction heterogeneity and enhanced AF susceptibility, despite normal atrial action potential duration and normal ventricular structure and function (Verheule et al. 2004).

Cardiac fibrosis driven by TGF- $\beta_{1}$ is negatively regulated by the bone morphogenic protein 7 (BMP-7) which also belongs to the TGF superfamily and uses SMADs for intracellular signaling. Systemic administration of the human recombinant BMP-7 inhibited cardiac fibrosis in a pressure-overloaded mouse model (Towbin 2007). It remains to demonstrate whether BMP-7 also plays a role in the structural remodeling of atria and risk of AF.

\section{Inflammation and reactive oxygen species}

Histological studies noted inflammatory cell infiltration and fibrosis in atrial biopsies of patients with lone AF (Frustaci et al. 1997). Inflammatory cell infiltration and calcium overload during high atrial rate may promote oxidative damage in atrial tissue which promotes atrial fibrosis and facilitates AF continuation. There is increasing evidence that oxidative stress and inflammation are relevant players in structural atrial remodeling.

The causal link between inflammation and $\mathrm{AF}$ was first proposed by Bruins et al. (1997). In patients who underwent coronary artery bypass surgery, the peak incidence of postoperative AF coincided with the peak in C-reactive protein (CRP) elevation. In a population study of 5,806 subjects aged 65 years or older, baseline CRP level predicted the future development of AF (Aviles et al. 2003). Moreover, lower hs-CRP at the baseline was associated with maintenance of sinus rhythm after planned electrical cardioversion for persistent $\mathrm{AF}$ (Tveit et al. 
2007). CRP may not be just a marker of current inflammation, but it may itself contribute to cardiac damage by activating the serum complement (Pepys et al. 2006). Whether complement-mediated inflammation plays a role in human AF remains to be demonstrated.

Mihm et al. (2001) showed that oxidative damage in the atrial myocardium of chronic AF patients is due to the local action of hydroxyl radicals and peroxynitrite. In a dog model, atrial tachy-pacing led to a decrease of ascorbic acid in the atrial tissue and to increased protein nitration (Carnes et al. 2001).

Examination of gene transcriptional profiles of human atrial tissue of AF patients showed a shift toward the pro-oxidative gene expression (Kim et al. 2003). The main contributors to atrial oxidative stress were myocardial NADPH-oxidase and uncoupled NO synthase (Kim et al. 2005). Furthermore, reactive oxygen species were indirectly stimulated by activation of the renin-angiotensin system. Activation of $\mathrm{AT}_{1}$ receptors increased NADPH oxidase-mediated superoxide production, and inhibition of $\mathrm{AT}_{1}$ receptors decreased oxidative stress in the vascular wall (Keaney 2005).

\section{Structural remodeling as a therapeutic target}

\section{Modulation of the renin-angiotensin-aldosterone system}

Because angiotensin II has a central role in the development of atrial fibrosis, inhibition of atrial ACE and $\mathrm{AT}_{1}$ receptors might be beneficial in $\mathrm{AF}$. In experimental models, AF susceptibility and atrial fibrosis were decreased by candesartan or enalapril, but not by hydralazine or isosorbide mononitrate despite similar hemodynamic effects (Okazaki et al. 2006, Li et al. 2001), thus suggesting a key role of targeting renin-angiotensin system, rather than of improving the hemodynamics. Meta-analysis of all trials using ACE inhibitors or angiotensin receptor blockers (ARB) showed that these drugs have quite potent antiarrhythmic effects. In the overall population, these drugs reduced new-onset AF by $18 \%$, and among heart failure patients as much as $43 \%$ (Anand et al. 2006). Blockade of the renin-angiotensin system also reduced the failure rate of electrical cardioversion and the recurrence of AF after electrical cardioversion (Kalus et al. 2006).

\section{Antagonism of the TGF- $\beta_{1}$ pathway}

Recent research has focused on modification of the TGF- $\beta_{1}$ pathway as a way to possible AF prevention or treatment. In pressure-overloaded rats, the administration of TGF- $\beta_{1}$ monoclonal antibodies prevented atrial fibrosis and diastolic dysfunction (Kuwahara et al. 2002). Koyanagi et al. (2000) found that anti-TGF- $\beta_{1}$ monoclonal antibodies prevented inflammatory changes by blocking the migration of monocytes in rat hearts and the recruitment of fibroblasts. Dogs with pacing-induced heart failure treated with the antifibrotic drug pirfenidone (a drug-reducing TGF- $\beta_{1}$ expression) had significant reduction in atrial remodeling and $\mathrm{AF}$ vulnerability (Lee et al. 2006). These favorable effects were associated with reduction in TGF- $\beta_{1}$ expression and atrial fibrosis.

Another promising antifibrotic agent is relaxin, a hormone responsible for extensive changes of the extracellular matrix in the female reproductive system during pregnancy. Both ventricular and atrial cells express receptors for relaxin. Relaxin attenuates expression of TGF- $\beta_{1}$ and its effects on fibroblast differentiation and matrix synthesis (Samuel et al. 2007). Whether relaxin might be useful for amelioration of AF substrate is still unknown.

\section{Statins and antioxidants}

Statins have anti-inflammatory and anti-oxidant effects; therefore, they might have a potentially beneficial effect on AF. In a canine atrial tachypacing model, simvastatin attenuated the promotion of AF (ShiroshitaTakeshita et al. 2007). In another study, Amar et al. (2005) demonstrated the beneficial effect of statins in patients after non-cardiac thoracic surgery. Preoperative statin administration was associated with a threefold decrease in the odds of developing AF independently of the change of CRP or interleukin-6.

Beneficial effects on AF occurrence were also documented using ascorbic acid. Oral ascorbic acid administration in patients with persistent AF reduced early recurrence of AF after cardioversion (Korantzopoulos et al. 2005).

\section{Corticosteroids}

In an animal model of sterile pericarditis, prednisone therapy reduced the incidence of $\mathrm{AF}$ (Shiroshita-Takeshita et al. 2006). In humans after successful cardioversion of AF, methylprednisolone (16 mg for 4 weeks tapering to $4 \mathrm{mg}$ for 4 months) reduced AF recurrence from $50 \%$ in the control group to $9.6 \%$ in the glucocorticoid group (Dernellis and Panaretou 2004).

Recently, a double-blind, randomized, multicentre Finnish trial (Halonen et al. 2007) demonstrated favorable 
effect of steroids on post-operative patients without prior $\mathrm{AF}$ or flutter, undergoing their first on-pump cardiac surgery, who were randomly subjected to glucocorticoid therapy with hydrocortisone or placebo. The incidence of post-operative AF during the first $84 \mathrm{~h}$ was significantly lower in the hydrocortisone group (30\%) than in the placebo group $(48 \%, \mathrm{p}=0.01)$, without increasing the rates of wound infection or other major complications. These results certainly support the causative role of inflammation in paroxysmal AF, but whether corticosteroids may offer obvious clinical benefit in the perioperative management of cardiac patients will need further study.

\section{Conclusions}

The origin and persistence of AF result from a complex interaction between triggers, substrate, and factors involved in atrial remodeling. It is obvious that the pathophysiology of AF differs from one patient to another, but recent advances have helped us to understand more about involved mechanisms and to translate this knowledge into improvements of AF therapy. An example could be the elimination of triggers within pulmonary veins by means of catheter ablation. Dealing with structural atrial remodeling and atrial fibrosis remains still a great challenge. Solving these problems could help us to develop new approaches to AF prevention and treatment.

\section{Conflict of Interest}

There is no conflict of interest.

\section{Acknowledgements}

This study is supported by grant MZO-00023001 from the Ministry of Health, Czech Republic.

\section{References}

ALLESSIE M, LAMMAERS W, BONKE FIM, HOLLEN J: Experimental evaluation of Moe's multiple wavelet hypothesis of atrial fibrillation. In: Cardiac Arrhythmias. DP ZIPES, J JALIFE (eds), Grune and Stratton, New York, 1985, pp 265-276.

AMAR D, ZHANG H, HEERDT PM, PARK B, FLEISHER M, THALER HT: Statin use is associated with a reduction in atrial fibrillation after noncardiac thoracic surgery independent of C-reactive protein. Chest 128: 3421-3427, 2005.

ANAND K, MOOSS AN, HEE TT, MOHIUDDIN SM: Meta-analysis: inhibition of renin-angiotensin system prevents new-onset atrial fibrillation. Am Heart J 152: 217-222, 2006.

ARDELL JL: Structure and function of mammalian intrinsic cardiac neurons. In: Neurocardiology. JA ARMOUR, JL ARDELL (eds), Oxford University Press, New York, 1994, pp 95-114.

ARMOUR JA, MURPHY DA, YUAN BX, MACDONALD S, HOPKINS DA: Gross and microscopic anatomy of the human intrinsic cardiac nervous system. Anat Rec 247: 289-298, 1997.

ARORA R, VERHEULE S, SCOTT L, NAVARRETE A, KATARI V, WILSON E, VAZ D, OLGIN JE: Arrhythmogenic substrate of the pulmonary veins assessed by high-resolution optical mapping. Circulation 107: 1816-1821, 2003.

ATIENZA F, JALIFE J: Reentry and atrial fibrillation. Heart Rhythm 4: S13-S16, 2007.

ATIENZA F, ALMENDRAL A, MORENO J, VAIDYANATHAN R, TALKACHOU A, KALIFA J, ARENAL A, VILLACASTÍN JP, TORRECILLA EG, SÁNCHEZ A, PLOUTZ-SNYDER R, JALIFE J, BERENFELD O: Activation of inward rectifier potassium channels accelerates atrial fibrillation in humans, evidence for a reentrant mechanism. Circulation 114: 2434-2442, 2006.

AUSMA J, WIJFFELS M, THONE F, WOUTERS L, ALLESSIE M, BORGERS M: Structural changes of atrial myocardium due to sustained atrial fibrillation in the goat. Circulation 96: 3157-3163, 1997.

AVILES RJ, MARTIN DO, PPERSON-HANSEN C, HOUGHTALING PL, RAUTAHARJU P, KRONMAL RA, TRACY RP, VAN WAGONER DR, PSATY BM, LAUER MS, CHUNG MK: Inflammation as a risk factor for atrial fibrillation. Circulation 108: 3006-3010, 2003.

BECKER AE: How structurally normal are human atria in patients with atrial fibrillation? Heart Rhythm 1: 627-631, 2004. 
BENJAMIN EJ, WOLF PA, D'AGOSTINO RB, SILBERSHATZ H, KANNEL WB, LEVY D: Impact of atrial fibrillation on the risk of death: the Framingham Heart Study. Circulation 98: 946-952, 1998.

BLAAUW Y, GÖGELEIN H, TIELEMAN RG, VAN HUNNIK A, SCHOTTEN U, ALLESSIE MA: "Early" class III drugs for the treatment of atrial fibrillation: efficacy and atrial selectivity of AVE0118 in remodeled atria of the goat. Circulation 110: 1717-1724, 2004.

BOLDT A, WETZEL U, LAUSCHKE J, WEIGL J, GUMMERT J, HINDRICKS G, KOTTKAMP H, DHEIN S: Fibrosis in left atrial tissue of patients with atrial fibrillation with and without underlying mitral valve disease. Heart 90: 400-405, 2004.

BRUINS P, TE VH, YAZDANBAKHSH AP, JANSEN PG, VAN HARDEVELT FW, DE BEAUMONT EM, WILDEVUUR CR, EIJSMAN L, TROUWBORST A, HACK CE: Activation of the complement system during and after cardiopulmonary bypass surgery: postsurgery activation involves C-reactive protein and is associated with postoperative arrhythmia. Circulation 96: 3542-3548, 1997.

CAMPBELL SE, KATWA LC: Angiotensin II stimulated expression of transforming growth factor-betal in cardiac fibroblasts and myofibroblasts. J Mol Cell Cardiol 29: 1947-1958, 1997.

CARDIN S, LI D, THORIN-TRESCASES N, LEUNG TK, THORIN E, NATTEL S: Evolution of the atrial fibrillation substrate in experimental congestive heart failure: angiotensin-dependent and -independent pathways. Cardiovasc Res 60: 315-325, 2003.

CARNES CA, CHUNG MK, NAKAYAMA T, NAKAYAMA H, BALIGA RS, PIAO S, KANDERIAN A, PAVIA S, HAMLIN RL, MCCARTHY PM, BAUER JA, VAN WAGONER DR: Ascorbate attenuates atrial pacinginduced peroxynitrite formation and electrical remodeling and decreases the incidence of postoperative atrial fibrillation. Circ Res 89: E32-E38, 2001.

CIPOLLONE F, FAZIA M, MINCIONE G, IEZZI A, PINI B, CUCCURULLO C, UCCHINO S, SPIGONARDO F, DI NISIO M, CUCCURULLO F, MEZZETTI A, PORRECA E: Increased expression of transforming growth factor-beta1 as a stabilizing factor in human atherosclerotic plaques. Stroke 35: 2253-2257, 2004.

COURTEMANCHE M, RAMIREZ RJ, NATTEL S: Ionic targets for drug therapy and atrial fibrillation-induced electrical remodeling: insights from a mathematical model. Cardiovasc Res 42: 477-489, 1999.

DERNELLIS J, PANARETOU M: Relationship between C-reactive protein concentrations during glucocorticoid therapy and recurrent atrial fibrillation. Eur Heart J 25: 1100-1107, 2004.

EHRLICH JR, CHA TJ, ZHANG L, CHARTIER D, MELNYK P, HOHNLOSER SH, NATTEL S: Cellular electrophysiology of canine pulmonary vein cardiomyocytes: action potential and ionic current properties. J Physiol Lond 551: 801-813, 2003.

EVERETT TH, OLGIN JE: Atrial fibrosis and the mechanisms of atrial fibrillation. Heart Rhythm 4: S24-S27, 2007.

FARRÉ J, WELLENS HJ: Philippe Coumel: a founding father of modern arrhythmology. Europace 6: 464-465, 2004.

FRUSTACI A, CHIMENTI C, BELLOCCI F, MORGANTE E, RUSSO MA, MASERI A: Histological substrate of atrial biopsies in patients with lone atrial fibrillation. Circulation 96: 1180-1184, 1997.

FUSTER V, RYDEN LE, CANNOM DS, CRIJNS HJ, CURTIS AB, ELLENBOGEN KA, HALPERIN JL, LE HEUZEY JY, KAY GN, LOWE JE, OLSSON SB, PRYSTOWSKY EN, TAMARGO JL, WANN S: ACC/AHA/ESC 2006 guidelines for the management of patients with atrial fibrillation-executive summary. Eur Heart J 27: 1979-2030, 2006.

GARREY WE: Auricular fibrillation. Physiol Rev 4: 215-250, 1924.

GASPO R, BOSCH RF, BOU-ABBOUD E, NATTEL S: Tachycardia-induced changes in $\mathrm{Na}^{+}$current in a chronic dog model of atrial fibrillation. Circ Res 81: 1045-1052, 1997.

GITTENBERGER-DE GROOT AC, BLOM NM, AOYAMA N, SUCOV H, WENINK AC, POELMANN RE: The role of neural crest and epicardium-derived cells in conduction system formation. Novartis Found Symp 250: 125-134, 2003.

HAISSAGUERRE M, JAIS P, SHAH DC, TAKAHASHI A, HOCINI M, QUINIOU G, GARRIGUE S, LE MA, LE MP, CLEMENTY J: Spontaneous initiation of atrial fibrillation by ectopic beats originating in the pulmonary veins. N Engl J Med 339: 659-666, 1998. 
HALONEN J, HALONEN P, JARVINEN O, TASKINEN P, AUVINEN T, TARKKA M, HIPPELAINEN M, JUVONEN T, HARTIKAINEN J, HAKALA T: Corticosteroids for the prevention of atrial fibrillation after cardiac surgery: a randomized controlled trial. JAMA 297: 1562-1567, 2007.

HO SY, SANCHEZ-QUINTANA D, CABRERA JA, ANDERSON RH: Anatomy of the left atrium: implications for radiofrequency ablation of atrial fibrillation. J Cardiovasc Electrophysiol 10: 1525-1533, 1999.

HONJO H, BOYETT MR, NIWA R, INADA S, YAMAMOTO M, MITSUI K, HORIUCHI T, SHIBATA N, KAMIYA K, KODAMA I: Pacing-induced spontaneous activity in myocardial sleeves of pulmonary veins after treatment with ryanodine. Circulation 107: 1937-1943, 2003.

HSU SY, NAKABAYASHI K, NISHI S, KUMAGAI J, KUDO M, SHERWOOD OD, HSUEH AJ: Activation of orphan receptors by the hormone relaxin. Science 295: 671-674, 2002.

KALUS JS, COLEMAN CI, WHITE CM: The impact of suppressing the renin-angiotensin system on atrial fibrillation. J Clin Pharmacol 46: 21-28, 2006.

KANGAVARI S, OH YS, ZHOU S, YOUN HJ, LEE MY, JUNG WS, RHO TH, HONG SJ, KAR S, KERWIN WF, SWERDLOW CD, GANG ES, GALLIK DM, GOODMAN JS, CHEN YD, CHEN PS: Radiofrequency catheter ablation and nerve growth factor concentration in humans. Heart Rhythm 3: 1150-1155, 2006.

KEANEY JF, Jr.: Oxidative stress and the vascular wall: NADPH oxidases take center stage. Circulation 112: 25852588, 2005.

KHAN R, SHEPPARD R: Fibrosis in heart disease: understanding the role of transforming growth factor-beta in cardiomyopathy, valvular disease and arrhythmia. Immunology 118: 10-24, 2006.

KIM S, OHTA K, HAMAGUCHI A, OMURA T, YUKIMURA T, MIURA K, INADA Y, ISHIMURA Y, CHATANI F, IWAO H: Angiotensin II type I receptor antagonist inhibits the gene expression of transforming growth factor-beta 1 and extracellular matrix in cardiac and vascular tissues of hypertensive rats. $J$ Pharmacol Exp Ther 273: 509-515, 1995.

KIM YH, LIM DS, LEE JH, SHIM WJ, RO YM, PARK GH, BECKER KG, CHO-CHUNG YS, KIM MK: Gene expression profiling of oxidative stress on atrial fibrillation in humans. Exp Mol Med 35: 336-349, 2003.

KIM YM, GUZIK TJ, ZHANG YH, ZHANG MH, KATTACH H, RATNATUNGA C, PILLAI R, CHANNON KM, CASADEI B: A myocardial Nox2 containing NAD(P)H oxidase contributes to oxidative stress in human atrial fibrillation. Circ Res 97: 629-636, 2005.

KORANTZOPOULOS P, KOLETTIS TM, KOUNTOURIS E, DIMITROULA V, KARANIKIS P, PAPPA E, SIOGAS K, GOUDEVENOS JA: Oral vitamin C administration reduces early recurrence rates after electrical cardioversion of persistent atrial fibrillation and attenuates associated inflammation. Int J Cardiol 102: 321326, 2005.

KOYANAGI M, EGASHIRA K, KUBO-INOUE M, USUI M, KITAMOTO S, TOMITA H, SHIMOKAWA H, TAKESHITA A: Role of transforming growth factor-betal in cardiovascular inflammatory changes induced by chronic inhibition of nitric oxide synthesis. Hypertension 35: 86-90, 2000.

KÜHLKAMP V, SCHIRDEWAN A, STANGL K, HOMBERG M, PLOCH M, BECK OA: Use of metoprolol CR/XL to maintain sinus rhythm after conversion from persistent atrial fibrillation: a randomized, double-blind, placebo-controlled study. J Am Coll Cardiol 36: 139-146, 2000.

KUPFAHL C, PINK D, FRIEDRICH K, ZURBRUGG HR, NEUSS M, WARNECKE C, FIELITZ J, GRAF K, FLECK E, REGITZ-ZAGROSEK V: Angiotensin II directly increases transforming growth factor beta1 and osteopontin and indirectly affects collagen mRNA expression in the human heart. Cardiovasc Res 46: 463-475, 2000.

KUWAHARA F, KAI H, TOKUDA K, KAI M, TAKESHITA A, EGASHIRA K, IMAIZUMI T: Transforming growth factor-beta function blocking prevents myocardial fibrosis and diastolic dysfunction in pressure-overloaded rats. Circulation 106: 130-135, 2002.

LEE KW, EVERETT TH, RAHMUTULA D, GUERRA JM, WILSON E, DING C, OLGIN JE: Pirfenidone prevents the development of a vulnerable substrate for atrial fibrillation in a canine model of heart failure. Circulation 114: 1703-1712, 2006.

LI D, FAREH S, LEUNG TK, NATTEL S: Promotion of atrial fibrillation by heart failure in dogs: atrial remodeling of a different sort. Circulation 100: 87-95, 1999. 
LI D, SHINAGAWA K, PANG L, LEUNG TK, CARDIN S, WANG Z, NATTEL S: Effects of angiotensin-converting enzyme inhibition on the development of the atrial fibrillation substrate in dogs with ventricular tachypacinginduced congestive heart failure. Circulation 104: 2608-2614, 2001.

MAISEL WH, RAWN JD, STEVENSON WG: Atrial fibrillation after cardiac surgery. Ann Intern Med 135: 10611073, 2001.

MIHM MJ, YU F, CARNES CA, REISER PJ, MCCARTHY PM, VAN WAGONER DR, BAUER JA: Impaired myofibrillar energetics and oxidative injury during human atrial fibrillation. Circulation 104: 174-180, 2001.

MITCHELL GF, VASAN RS, KEYES MJ, PARISE H, WANG TJ, LARSON MG, D'AGOSTINO RB, Sr., KANNEL WB, LEVY D, BENJAMIN EJ: Pulse pressure and risk of new-onset atrial fibrillation. JAMA 297: 709-715, 2007.

MOE GK, RHEINBOLDT WC, ABILDSKOV JA: A computer model of atrial fibrillation. Am Heart $J$ 67: 200-220, 1964.

MORILLO CA, KLEIN GJ, JONES DL, GUIRAUDON CM: Chronic rapid atrial pacing. Structural, functional, and electrophysiological characteristics of a new model of sustained atrial fibrillation. Circulation 91: 1588-1595, 1995.

NADEMANEE K, MCKENZIE J, KOSAR E, SCHWAB M, SUNSANEEWITAYAKUL B, VASAVAKUL T, KHUNNAWAT C, NGARMUKOS T: A new approach for catheter ablation of atrial fibrillation: mapping of the electrophysiologic substrate. J Am Coll Cardiol 43: 2044-2053, 2004.

OH S, ZHANG Y, BIBEVSKI S, MARROUCHE NF, NATALE A, MAZGALEV TN: Vagal denervation and atrial fibrillation inducibility: epicardial fat pad ablation does not have long-term effects. Heart Rhythm 3: 701-708, 2006.

OKAZAKI H, MINAMINO T, TSUKAMOTO O, KIM J, OKADA K, MYOISHI M, WAKENO M, TAKASHIMA S, MOCHIZUKI N, KITAKAZE M: Angiotensin II type 1 receptor blocker prevents atrial structural remodeling in rats with hypertension induced by chronic nitric oxide inhibition. Hypertens Res 29: 277-284, 2006.

OKUYAMA Y, PAK HN, MIYAUCHI Y, LIU YB, CHOU CC, HAYASHI H, FU KJ, KERWIN WF, KAR S, HATA C, KARAGUEUZIAN HS, FISHBEIN MC, CHEN PS, CHEN LS: Nerve sprouting induced by radiofrequency catheter ablation in dogs. Heart Rhythm 1: 712-717, 2004.

PANDOZI C, BIANCONI L, VILLANI M, GENTILUCCI G, CASTRO A, ALTAMURA G, JESI AP, LAMBERTI F, AMMIRATI F, SANTINI M: Electrophysiological characteristics of the human atria after cardioversion of persistent atrial fibrillation. Circulation 98: 2860-2865, 1998.

PAPPONE C, SANTINELLI V, MANGUSO F, VICEDOMINI G, GUGLIOTTA F, AUGELLO G, MAZZONE P, TORTORIELLO V, LANDONI G, ZANGRILLO A, LANG C, TOMITA T, MESAS C, MASTELLA E, ALFIERI O: Pulmonary vein denervation enhances long-term benefit after circumferential ablation for paroxysmal atrial fibrillation. Circulation 109: 327-334, 2004.

PEPYS MB, HIRSCHFIELD GM, TENNENT GA, GALLIMORE JR, KAHAN MC, BELLOTTI V, HAWKINS PN, MYERS RM, SMITH MD, POLARA A, COBB AJ, LEY SV, AQUILINA JA, ROBINSON CV, SHARIF I, GRAY GA, SABIN CA, JENVEY MC, KOLSTOE SE, THOMPSON D, WOOD SP: Targeting C-reactive protein for the treatment of cardiovascular disease. Nature 440: 1217-1221, 2006.

SAMUEL CS, HEWITSON TD, UNEMORI EN, TANG ML: Drugs of the future: the hormone relaxin. Cell Mol Life Sci 64: 1539-1557, 2007.

SCHERLAG BJ, YAMANASHI W, PATEL U, LAZZARA R, JACKMAN WM: Autonomically induced conversion of pulmonary vein focal firing into atrial fibrillation. $J$ Am Coll Cardiol 45: 1878-1886, 2005.

SCHULTZ JJ, WITT SA, GLASCOCK BJ, NIEMAN ML, REISER PJ, NIX SL, KIMBALL TR, DOETSCHMAN T: TGF-beta1 mediates the hypertrophic cardiomyocyte growth induced by angiotensin II. J Clin Invest 109: 787796, 2002.

SHINAGAWA K, SHIROSHITA-TAKESHITA A, SCHRAM G, NATTEL S: Effects of antiarrhythmic drugs on fibrillation in the remodeled atrium: insights into the mechanism of the superior efficacy of amiodarone. Circulation 107: 1440-1446.

SHIROSHITA-TAKESHITA A, BRUNDEL BJ, LAVOIE J, NATTEL S: Prednisone prevents atrial fibrillation promotion by atrial tachycardia remodeling in dogs. Cardiovasc Res 69: 865-875, 2006. 
SHIROSHITA-TAKESHITA A, BRUNDEL BJ, BURSTEIN B, LEUNG TK, MITAMURA H, OGAWA S, NATTEL S: Effects of simvastatin on the development of the atrial fibrillation substrate in dogs with congestive heart failure. Cardiovasc Res 74: 75-84, 2007.

TAN AY, LI H, WACHSMANN-HOGIU S, CHEN LS, CHEN PS, FISHBEIN MC: Autonomic innervation and segmental muscular disconnections at the human pulmonary vein-atrial junction: implications for catheter ablation of atrial-pulmonary vein junction. $J$ Am Coll Cardiol 48: 132-143, 2006.

TIELEMAN RG, VAN GELDER IC, BOSKER HA, KINGMA T, WILDE AA, KIRCHHOF CJ, BENNEKERS JH, BRACKE FA, VEEGER NJ, HAAKSMA J, ALLESSIE MA, CRIJNS HJ: Does flecainide regain its antiarrhythmic activity after electrical cardioversion of persistent atrial fibrillation? Heart Rhythm 2: 223-230, 2005.

TOWBIN JA: Scarring in the heart--a reversible phenomenon? N Engl J Med 357: 1767-1768, 2007.

TVEIT A, SELJEFLOT I, GRUNDVOLD I, ABDELNOOR M, SMITH P, ARNESEN H: Effect of candesartan and various inflammatory markers on maintenance of sinus rhythm after electrical cardioversion for atrial fibrillation. Am J Cardiol 99: 1544-1548, 2007.

VERHEULE S, SATO T, EVERETT T, ENGLE SK, OTTEN D, RUBART-VON DER LOHE M, NAKAJIMA HO, NAKAJIMA H, FIELD LJ, OLGIN JE: Increased vulnerability to atrial fibrillation in transgenic mice with selective atrial fibrosis caused by overexpression of TGF-beta1. Circ Res 94: 1458-1465, 2004.

WIJFFELS MC, KIRCHHOF CJ, DORLAND R, ALLESSIE MA: Atrial fibrillation begets atrial fibrillation. A study in awake chronically instrumented goats. Circulation 92: 1954-1968, 1995.

WIT AL, BOYDEN PA: Triggered activity and atrial fibrillation. Heart Rhythm 4 (3 Suppl): S17-S23, 2007.

YUE L, FENG J, GASPO R, LI GR, WANG Z, NATTEL S: Ionic remodeling underlying action potential changes in a canine model of atrial fibrillation. Circ Res 81: 512-525, 1997.

ZHOU S, CHANG CM, WU TJ, MIYAUCHI Y, OKUYAMA Y, PARK AM, HAMABE A, OMICHI C, HAYASHI H, BRODSKY LA, MANDEL WJ, TING CT, FISHBEIN MC, KARAGUEUZIAN HS, CHEN PS: Nonreentrant focal activations in pulmonary veins in canine model of sustained atrial fibrillation. Am J Physiol 283: H1244-H1252, 2002.

ZIPES DP, MIHALICK MJ, ROBBINS GT: Effects of selective vagal and stellate ganglion stimulation of atrial refractoriness. Cardiovasc Res 8: 647-655, 1974. 